\title{
Comparative effects of mechanized and manual tillage practices on soil properties and the yield of seed yam in Southwest Nigeria
}

\author{
F. O. ADEKAYODE ${ }^{1 *}$ AND M. O. OGUNKOYA $^{2}$ \\ ${ }^{l}$ Department of Crop, Soil and Pest Management, Federal University of Technology, Akure, Nigeria. \\ ${ }^{2}$ Federal College of Agriculture, Akure, Nigeria. \\ *Corresponding author, E-mail: adekay98@yahoo.com
}

\begin{abstract}
The effects of various tillage systems on soil physical and chemical properties and the yield of seed yam were investigated and compared in a research conducted in Akure (Latitude $7^{0} 18^{\prime} \mathrm{N}$ and Longitude $5^{0} 15$ 'E)-Nigeria in 2008 and 2009. Three tillage systems comprising ploughing plus harrowing, ploughing plus harrowing plus ridging and manual ridging were replicated three times in a randomized complete block experimental design. Healthy yam tubers weighing about $1 \mathrm{~kg}$ were cut into minisetts of about $25 \mathrm{~g}$, treated with a mixture of wood ash and demosan fungicide and planted in nursery made of moist sawdust. The minisetts sprouted after three weeks and at four weeks, transplanted to the field prepared under the various tillage methods. $100 \mathrm{~kg} / \mathrm{ha}$ NPK 15-15-15 were applied at eight weeks after transplanting the seed yam seedlings while soil physical and chemical properties were taken at five months and the harvesting of seed yam done at six months after transplanting the seedlings. Soil bulk density was significantly high with a correspondingly lower porosity in the ploughed plus harrowing plot while the least values were observed in the ploughing plus harrowing plus ridging plot. The organic matter, nitrogen, phosphorus, potassium and the cation exchange capacity were in the medium adequate range for good seed yam growth. Bulk density was a major factor that influenced seed yam performance with the ridged plots producing lower bulk density and higher tuber weight and yield. The tuber weight and yield were comparable in both the mechanically and manually ridged plots.
\end{abstract}

(C) 2011 International Formulae Group. All rights reserved.

Keywords: Mechanized and manual tillage, comparative effects, soil properties, seed yam yield.

\section{INTRODUCTION}

The production of yam, an important staple food crop in humid tropical countries, had been constrained by the non-availability of planting materials of either seed yam or yam setts though other constraining factors included high cost of labour and declining soil fertility (Ike and Inoni, 2006; Ibana et al., 2009). Traditionally, farmers would reserve about thirty percent of the previous yam harvest for production of yam setts as planting materials for the following year and this had always resulted in reduced yam output (Ike and Inoni, 2006; Shehu et al., 2010).

In order to increase yam production, there was the need for an increased production of seed yam as the planting materials for which a breakthrough was made by the National Root Crops Research Institute (NRCRI) Umudike, and International Institute of Tropical Agriculture (IITA) Ibadan both in Nigeria for the production of seed yam by the 
yam minisett techniques (Okoli et al., 1982; Otoo et al., 1987). The yam minisetts were obtained when the mother seed yam was cut into several cylindrical pieces of about $5 \mathrm{~cm}$ long and the cylindrical pieces further cut longitudinally into more pieces (Okoro, 2008). The success of the yam minisett technique was measured by the corroborative research output observed later by researches that indicated increased production of seed yam by the technique (Madukwe et al., 2000; Bolarinwa and Oladeji, 2009). The wide adoptability of the minisett technique by large number of farmers in yam producing zones was also an indication of the success of the earlier research (Okoro, 2008; Udoh et al., 2008). There was however an observed decline in the adoption of the technique among yam farmers in some areas as reported in the findings of Okoro (1999) and Nnadi and Akwiwu (2007).

Yams require well pulverized loose soil with high organic matter levels for easy penetration and swelling of the tuber and therefore a shallow and compacted soil should be avoided for the production (Bamire and Amujoyegbe, 2005). The need to loosen the soil for yam had been necessary since unlike most other tuber crops, tuber formation would not be preceded by stolon-like structure and only the blunt tail-end of the tuber would penetrate through the soil (Onwueme, 1978). The requirement for ridging for an improved performance and yield of seed yam had been emphasized in previous research (Ijoyah et al., 2006). Extensive research had been carried out on mechanized ridging in improving the performance and yield of seed yam whereas the few available tractors for mechanization would not meet the need of the large number of small holder seed yam farmers to produce planting materials for the production of ware yams. The seed yams were the planting materials used in the field production of ware or table yam consumed as food (Oguntade et al., 2010). The need to forestall further discontinuance of seed yam production by farmers as reported in Nnadi and Akwiwu (2007) had created the desirability to conduct more research on the effectiveness of manual ridging as an alternative to mechanized ridging in seed yam production. The objective of this research was to compare the effects of ploughing plus harrowing $(\mathrm{P}+\mathrm{Hr})$, mechanized ploughing plus harrowing plus ridging $(\mathrm{P}+\mathrm{Hr}+\mathrm{R})$ and manual ridging $(\mathrm{MR})$ tillage systems on soil physical and chemical properties and the yield of seed yam in tropical rainforest of Southwest Nigeria.

\section{MATERIALS AND METHODS \\ Site description}

The experiment was carried out at the Edu Research Farm in the Federal College of Agriculture Akure Nigeria in 2008 and 2009. The project site was located on Latitude $7^{0} 18^{\prime} \mathrm{N}$ and Longitude $5^{0} 15^{\prime} \mathrm{E}$. Soil at the project site was an alfisol derived from medium grained granite and gneiss (Periaswamy and Ashaye, 1982). The rainfall pattern was bimodal with a definite cycle of rainy season of March to October and dry season of November to February (Akintola, 1986). The experimental site had been left fallow for five years before the commencement of the experiment and the predominant weed was Chromolaena odorata Preparation of seed yam seedlings in the nursery

Clean healthy yam tuber weighing 200 to $500 \mathrm{~g}$ was cut into minisetts with each weighing about $25 \mathrm{~g}$ and having the outer layer of skin or periderm. The treatment of the minisett against insect attack involved adding $24 \mathrm{~g}$ (a sachet) demosan pre-treatment chemical and two handfuls of wood ash into four liters of water in a plastic bowl. The minisetts were all put in a medium size plastic basket and dipped in and out several times in the demosan wood ash water mixture. This operation was to ensure that the surfaces of the minisetts were well covered with the chemical mixture. Minisetts were later spread under shed to air dry overnight and presprouted in a nursery. The nursery consisted of baskets filled with about three centimeter layer of fresh moist sawdust. Minisetts with the cut surfaces upward were placed in the sawdust and then covered with another three centimeter layer of fresh moist sawdust. After three to four weeks, minisetts had begun to sprout and the sprouted minisett seedlings transplanted into the field. 


\section{Soil sampling before tillage treatment and planting}

Prior to the commencement of the experiment in 2008, fifteen core (4 cm diameter, $10 \mathrm{~cm}$ high) soil samples were collected randomly from 0 to $15 \mathrm{~cm}$ depth in the site using soil auger, mixed thoroughly and the bulk sample taken to the laboratory, air dried and sieved to pass through a $2 \mathrm{~mm}$ screen for soil physical and chemical analyses.

\section{Field experiment}

Three tillage systems comprising ploughing plus harrowing $(\mathrm{P}+\mathrm{Hr})$, ploughing plus harrowing plus ridging $(\mathrm{P}+\mathrm{Hr}+\mathrm{R})$ and manual ridging (MR) were replicated three times in a randomized complete block experimental design. The size of each treatment plot was $5 \mathrm{~m}^{2}$ with a $5 \mathrm{~m}$ distance between the plots for easy maneuvering of tractors with implements. The minisett seedlings were planted at a spacing of $25 \mathrm{~cm}$ on ridges $90 \mathrm{~cm}$ apart to give a plant population of 44,000 seedlings per hectare and 100 seedlings per plot. There were four ridges five meters long in each of the ridged $(\mathrm{P}+\mathrm{Hr}+\mathrm{R}$ and $\mathrm{MR})$ plots while in the $\mathrm{P}+\mathrm{Hr}$ plot planting was $25 \mathrm{~cm}$ x $90 \mathrm{~cm}$. NPK 15-1515 was applied at $100 \mathrm{~kg} / \mathrm{ha}$ which corresponded to $2.25 \mathrm{~g}$ per seedling in band rows on both sides of the plant at 8 weeks after transplanting while supplementary hand weeding was carried out at 10 weeks after transplanting and staking done by the trellis method. Five plants on each ridge in a treatment plot were harvested at six months after transplanting for the seed yam yield parameters of stand survival at harvest, percentage marketable yield, tuber weight per stand and tuber yield per hectare. The tubers were cured for three days and subsequently placed on racks in a barn.

\section{Soil sampling at harvest for analysis}

The soil bulk density, porosity and the volumetric water content were determined by the core method while soil temperature was taken with the soil thermometer. The core (4 $\mathrm{cm}$ diameter, $10 \mathrm{~cm}$ high) soil samples were weighed, oven dried for twenty four hours at $105{ }^{0} \mathrm{C}$ or to constant weight and reweighed and the calculations worked out as explained in Brady and Weil (1999).
For the determination of the soil chemical properties, core soil samples on each bed in a treatment plot were bulked air-dried and sieved through a $2 \mathrm{~mm}$ sieve and analysed following the laboratory procedures described by Carter (1993). The soil pH was determined in water using a glass electrode $\mathrm{pH}$ meter. Organic carbon was determined by oxidising soil sample with dichromate solution and later titrated with ferrous sulphate solution. The total nitrogen was determined using MicroKjeldahl method and the available phosphorus determined by the Bray P-1 method. The exchangeable cations were extracted by leaching $5 \mathrm{~g}$ of soil with $50 \mathrm{ml}$ ammonium acetate at $\mathrm{pH} 7$. Potassium and sodium in the leachate were determined with a flame spectrophotometer while calcium and magnesium were determined with atomic absorption spectrophotometer. The exchangeable acidity was determined by adding barium chloride buffer solution to soil sample and titrated against $0.1 \mathrm{~N} \mathrm{HCl}$.

\section{Statistical analysis}

Data were collected in 2008, 2009 and subjected to analysis of variance (ANOVA) multiway classification with the treatment means compared using the Least Significant Difference (LSD) at $5 \%$ probability.

\section{RESULTS}

Table 1 shows the soil physical and chemical properties before the commencement of the experiment in 2008. The soils were sandy loam and slightly acidic. The bulk density was $1.79 \mathrm{~g} / \mathrm{cc}$ with a corresponding soil total porosity of $32.5 \%$. The organic matter, total nitrogen, available phosphorus and exchangeable potassium, calcium and magnesium and the cation exchange capacity were at medium levels.

Table 2 shows the soil physical properties at harvest in 2008 and 2009 respectively. The bulk density was significantly high in $\mathrm{P}+\mathrm{Hr}$ plot compared to the ridged plots while there was no significant differences between the mechanically and the manually ridged plots although the mechanically ridged plot of $\mathrm{P}+\mathrm{Hr}+\mathrm{R}$ plots had the least bulk density value. There was correspondingly higher porosity in ridged 
plots compared to the $\mathrm{P}+\mathrm{Hr}$ plot while the volumetric water content ranged between $23.57 \%$ and $24.35 \%$ with the soil temperature ranging between $28.5{ }^{\circ} \mathrm{C}$ and 29.6 ${ }^{0} \mathrm{C}$.

The trend in bulk density showed a negative correlation with seed yam yield with correlation coefficient values of -0.99 in each of 2008 and 2009 production years respectively while soil porosity showed correspondingly positive correlation coefficient values of 0.99 with seed yam yield in each of 2008 and 2009 production years respectively.

Tables 3 and 4 show the soil chemical properties at harvest in 2008 and 2009 respectively. The $\mathrm{pH}$ values did not show any significant differences in all the treatment plots in 2008 while in the second year 2009 , there was observed higher significant $\mathrm{pH}$ value in $\mathrm{MR}$ plot followed by $\mathrm{P}+\mathrm{Hr}+\mathrm{R}$ and $\mathrm{P}+\mathrm{Hr}$ in a decreasing order of magnitude which indicated a higher soil acidity in the $\mathrm{P}+\mathrm{Hr}$ plot than the ridged plots. In each of the two years, the values of organic matter, nitrogen, phosphorus, potassium, calcium, magnesium and the cation exchange capacity were higher in the MR plot, followed by $\mathrm{P}+\mathrm{Hr}+\mathrm{R}$ and $\mathrm{P}+\mathrm{Hr}$ in decreasing order of magnitude. The values of soil nutrients in all the treatment plots were in the medium range supportive of good seed yam performance and yield.

Table 5 shows the seed yam yield parameters in 2008 and 2009 respectively. The seed yam stand survival at harvest showed significantly higher values in the ridged plots compared to $\mathrm{P}+\mathrm{Hr}$ plot with the highest value obtained in $\mathrm{P}+\mathrm{Hr}+\mathrm{R}$ plot followed by $\mathrm{MR}$ and $\mathrm{P}+\mathrm{Hr}$ plots in decreasing order of magnitude. The highest marketable yield was observed in $\mathrm{P}+\mathrm{Hr}+\mathrm{R}$ plot with the lowest value observed in $\mathrm{P}+\mathrm{Hr}$ plot. The tuber weight per stand and the tuber yield per hectare followed a similar trend of significantly higher values obtained in the ridged plots compared to $\mathrm{P}+\mathrm{Hr}$ with the highest value obtained in $\mathrm{P}+\mathrm{Hr}+\mathrm{R}$ followed by $\mathrm{MR}$ and $\mathrm{P}+\mathrm{Hr}$ in decreasing order of magnitude. There were however no significant differences between the yield values of mechanically ridged $(\mathrm{P}+\mathrm{Hr}+\mathrm{R})$ and the manually ridged $(\mathrm{MR})$ plots. The percentage increase in yield in $\mathrm{P}+\mathrm{Hr}+\mathrm{R}$ over $\mathrm{MR}$ and $\mathrm{P}+\mathrm{Hr}$ were $4.05 \%$ and $202.24 \%$ respectively in 2008 while in 2009 the yield increase were $4.44 \%$ and $209.23 \%$ respectively.

Table 1: Physical and chemical properties of soils $(0-15 \mathrm{~cm}$ depth) in the experimental site in 2008 before the commencement of the experiment.

\begin{tabular}{ll}
\hline Soil property & Values \\
\hline Sand $(\%)$ & 65 \\
Silt $(\%)$ & 12 \\
Clay $(\%)$ & 23 \\
Soil texture & Sandy loam \\
Bulk density & 1.79 \\
Total porosity & $32.5 \%$ \\
$\mathrm{pH}\left(\mathrm{H}_{2} \mathrm{O}\right)$ & 6.5 \\
Organic matter $(\mathrm{g} / \mathrm{kg})$ & 2.87 \\
Total $\mathrm{N}(\mathrm{g} / \mathrm{kg})$ & 0.26 \\
Available $\mathrm{P}(\mathrm{mg} / \mathrm{kg})$ & 10.1 \\
Exchangeable $\mathrm{K}(\mathrm{cmol} / \mathrm{kg})$ & 0.17 \\
Exchangeable $\mathrm{Na}(\mathrm{cmol} / \mathrm{kg})$ & 0.15 \\
Exchangeable $\mathrm{Ca}(\mathrm{cmol} / \mathrm{kg})$ & 2.42 \\
Exchangeable $\mathrm{Mg}(\mathrm{cmol} / \mathrm{kg})$ & 0.98 \\
Cation Exchange Capacity $(\mathrm{cmol} / \mathrm{kg})$ & 3.84 \\
\hline
\end{tabular}


Table 2: Soil physical properties at harvest in 2008 and 2009.

\begin{tabular}{|c|c|c|c|c|c|c|c|c|}
\hline \multirow[t]{2}{*}{ Treatment } & \multicolumn{2}{|c|}{$\begin{array}{l}\text { Bulk density } \\
\text { (g/cc) }\end{array}$} & \multicolumn{2}{|c|}{ Porosity (\%) } & \multicolumn{2}{|c|}{$\begin{array}{l}\text { Volumetric water } \\
\text { content }(\%)\end{array}$} & \multicolumn{2}{|c|}{$\begin{array}{l}\text { Temperature } \\
\left({ }^{0} \mathrm{C}\right)\end{array}$} \\
\hline & 2008 & 2009 & 2008 & 2009 & 2008 & 2009 & 2008 & 2009 \\
\hline $\begin{array}{l}\text { Ploughing plus } \\
\text { harrowing (P+Hr) }\end{array}$ & 1.56 & 1.57 & 41.13 & 40.75 & 27.57 & 27.61 & 28.5 & 28.5 \\
\hline $\begin{array}{l}\text { Ploughing plus } \\
\text { harrowin ng plus } \\
\text { ridging ( } \mathrm{P}+\mathrm{Hr}+\mathrm{R})\end{array}$ & 1.33 & 1.35 & 48.81 & 49.16 & 23.57 & 23.67 & 29.4 & 29.4 \\
\hline $\begin{array}{l}\text { Manual ridging } \\
\text { (MR) }\end{array}$ & 1.38 & 1.36 & 47.92 & 47.62 & 24.33 & 24.35 & 29.4 & 29.6 \\
\hline $\operatorname{LSD}(0.05)$ & 0.06 & 0.05 & 0.75 & 0.60 & 0.68 & 0.81 & 0.6 & 0.3 \\
\hline
\end{tabular}

\section{DISCUSSION}

Effect of tillage practices on soil physical properties and the yield of seed yam

The sandy loam texture in the pretreatment soil analysis in Table 1 showed the suitability of the project site for the seed yam experimentation. Previous research had indicated soils of major yam growing areas to be dominated by sandy clay loam and sandy loam which showed the preponderance of loamy soil texture (Diby et al., 2009).

The reduced bulk density values of 1.33 $\mathrm{g} / \mathrm{cc}, 1.38 \mathrm{~g} / \mathrm{cc}$ and $1.56 \mathrm{~g} / \mathrm{cc}$ in $\mathrm{P}+\mathrm{Hr}+\mathrm{R}, \mathrm{MR}$ and $\mathrm{P}+\mathrm{Hr}$ respectively over the $1.79 \mathrm{~g} / \mathrm{cc}$ of the pre-treatment soil analysis was as a result of tillage operations that pulverized the soil. The significantly higher value observed in $\mathrm{P}+\mathrm{Hr}$ compared to the other treatment plots indicated a greater turning of the soil in the ridged plots while the comparable values between the $\mathrm{P}+\mathrm{Hr}+\mathrm{R}$ and $\mathrm{MR}$ showed that manual ridging could produce the same reduced bulk density as in mechanized ridging. The reduced bulk density values had corresponding increased total porosity values as found in Table 2. Soil bulk density had been described as an indicator of soil structure and soil compaction (Martinez and Zinck 2004). An increase in soil compaction would lead to an increase in soil bulk density with a consequent decrease in total porosity. The result among others would be a limitation in seed and root development of plants, resulting in a decrease in crop productivity. The effects of bulk density on the performance and yield of yam and seed yam had been reported in previous research as indicated in Ennin et al. (2009) that stated a high soil bulk density to be unfavourable for yam production while Orkwor and Asadu (1998) observed bulk density that ranged between 1.20 and 1.62 $\mathrm{g} / \mathrm{cc}$ to be suitable for good yam performance.

The effects of land preparation methods for well pulverized, loose soil consistence for the easy penetration and swelling of yam tubers had also been previously reported (Bamire and Amujoyegbe, 2005; Ijoyah et al., 2006). Tuber crops are sensitive to soil compaction and inadequate aeration and therefore the significantly higher seed yam stand survival, marketable yield, tuber weight and yield per hectare obtained in the ridged plots could therefore be adduced to the lower bulk density values and the higher total porosity. The lower yield values of $3.57 \mathrm{t} / \mathrm{ha}$ observed in the unridged compared to the ridged plots was because in the unridged $\mathrm{P}+\mathrm{Hr}$, the loose layer was only a few centimeters deep and the tail end of the tuber in the early developing stage encountered the unploughed soil layer below while the comparable bulk density and total porosity values between the mechanically $(\mathrm{P}+\mathrm{Hr}+\mathrm{R})$ 
F. O. ADEKAYODE et al. / Int. J. Biol. Chem. Sci. 5(4): 1423-1431, 2011

Table 3: Soil chemical properties at harvest in 2008.

\begin{tabular}{llllllllll}
\hline Treatment & $\mathbf{p H}$ & $\begin{array}{l}\text { Organic } \\
\text { matter } \\
(\mathbf{g} / \mathbf{k g})\end{array}$ & $\begin{array}{l}\mathbf{N} \\
(\mathbf{g} / \mathbf{k g})\end{array}$ & $\begin{array}{l}\mathbf{P} \\
(\mathbf{m g} / \mathbf{k g})\end{array}$ & $\mathbf{K}$ & $\mathbf{N a}$ & $\mathbf{C a}$ & $\mathbf{M g}$ & $\mathbf{C E C}$ \\
\hline $\begin{array}{l}\text { Ploughing plus } \\
\text { harrowing (P+Hr) }\end{array}$ & 5.3 & 2.51 & 0.22 & 7.80 & 0.32 & 0.12 & 2.79 & 0.60 & 3.92 \\
\hline $\begin{array}{l}\text { Ploughing plus } \\
\text { harrowing plus } \\
\text { ridging (P+Hr+R) }\end{array}$ & 5.5 & 2.58 & 0.24 & 8.61 & 0.36 & 0.13 & 2.85 & 0.63 & 4.02 \\
\hline $\begin{array}{l}\text { Manual ridging } \\
\text { (MR) }\end{array}$ & 6.0 & 2.84 & 0.25 & 9.82 & 0.37 & 0.13 & 3.11 & 0.77 & 4.30 \\
\hline LSD (0.05) & $\mathrm{NS}$ & 0.05 & 0.02 & 1.24 & 0.07 & $\mathrm{NS}$ & 0.15 & 0.09 & 0.23 \\
\hline
\end{tabular}

Table 4: Soil chemical properties at harvest in 2009.

\begin{tabular}{|c|c|c|c|c|c|c|c|c|c|}
\hline Treatment & pH & $\begin{array}{l}\text { Organic } \\
\text { matter } \\
(\mathrm{g} / \mathrm{kg})\end{array}$ & $\begin{array}{l}\mathbf{N} \\
(\mathrm{g} / \mathrm{kg})\end{array}$ & $\begin{array}{l}P \\
(\mathrm{mg} / \mathrm{kg})\end{array}$ & $\mathbf{K}$ & $\mathbf{N a}$ & $\begin{array}{l}\mathrm{Ca} \\
\mathrm{cmol} / \mathrm{kg}\end{array}$ & Mg & CEC \\
\hline $\begin{array}{l}\text { Ploughing plus } \\
\text { harrowing }(\mathbf{P}+\mathrm{Hr})\end{array}$ & 5.4 & 2.50 & 0.23 & 8.13 & 0.33 & 0.12 & 2.76 & 0.60 & 3.90 \\
\hline $\begin{array}{l}\text { Ploughing plus } \\
\text { harrowing plus } \\
\text { ridging }(\mathrm{P}+\mathrm{Hr}+\mathrm{R})\end{array}$ & 5.6 & 2.54 & 0.25 & 8.87 & 0.36 & 0.13 & 2.84 & 0.62 & 4.02 \\
\hline $\begin{array}{l}\text { Manual ridging } \\
\text { (MR) }\end{array}$ & 6.1 & 2.85 & 0.26 & 9.57 & 0.37 & 0.14 & 3.02 & 0.74 & 4.28 \\
\hline LSD (0.05) & 0.3 & 0.05 & NS & 1.01 & 0.03 & NS & 0.10 & 0.04 & 0.06 \\
\hline
\end{tabular}


Table 5: Seed yam yield parameters in 2008 and 2009.

\begin{tabular}{lcccccccc}
\hline Treatment & $\begin{array}{l}\text { Stand survival } \\
\text { at harvest (\%) }\end{array}$ & \multicolumn{2}{c}{$\begin{array}{c}\text { Marketable } \\
\text { yield }(\boldsymbol{\%})\end{array}$} & \multicolumn{2}{c}{$\begin{array}{c}\text { Tuber weight } \\
\text { per stand }(\mathbf{g})\end{array}$} & \multicolumn{2}{c}{$\begin{array}{c}\text { Tuber yield } \\
\text { (t/ha) }\end{array}$} \\
\cline { 2 - 9 } & $\mathbf{2 0 0 8}$ & $\mathbf{2 0 0 9}$ & $\mathbf{2 0 0 8}$ & $\mathbf{2 0 0 9}$ & $\mathbf{2 0 0 8}$ & $\mathbf{2 0 0 9}$ & $\mathbf{2 0 0 8}$ & $\mathbf{2 0 0 9}$ \\
\hline $\begin{array}{l}\text { Ploughing plus } \\
\text { harrowing } \\
\text { (P+Hr) }\end{array}$ & 58.73 & 58.57 & 71.53 & 71.83 & 192.5 & 191.3 & 3.57 & 3.57 \\
\hline $\begin{array}{l}\text { Ploughing plus } \\
\text { harrowin ng plus } \\
\text { ridging } \\
\text { (P+Hr+R) }\end{array}$ & 96.80 & 96.97 & 89.50 & 90.37 & 281.3 & 287.5 & 10.79 & 11.04 \\
\hline $\begin{array}{l}\text { Manual ridging } \\
\text { (MR) }\end{array}$ & 95.07 & 94.96 & 89.43 & 89.20 & 276.4 & 281.8 & 10.37 & 10.57 \\
\hline LSD $(0.05)$ & 4.67 & 0.57 & 0.62 & 2.04 & 6.6 & 9.3 & 0.30 & 0.25 \\
\hline
\end{tabular}

and the manually (MR) ridged plots reflected in the comparable yield parameters of stand survival, marketable yield, tuber weight and tuber yield per hectare. Ennin et al. (2009) had reported the advantages of ridging to be in addition to the provision of loose seed-beds, the collection of fertile top soil and the ease of harvesting. The soil temperature range of 28.5 ${ }^{0} \mathrm{C}$ and $29.6{ }^{\circ} \mathrm{C}$ was conducive to good yam growth as reported in Orkwor and Asadu (1998) of the optimum temperature range of yam to be $20{ }^{\circ} \mathrm{C}$ to $30{ }^{\circ} \mathrm{C}$.

Effect of tillage treatments on the chemical properties and the yield of seed yam

The pre-treatment soil analysis in Table 1 showed that nutrient content of the soils in the experimental site was in the medium range and therefore suitable for good yam/seed yam performance. The supplemental application of $100 \mathrm{~kg} / \mathrm{ha}$ NPK 15-15-15 was to ensure adequate supply of nitrogen, phosphorus and potassium. Yams respond positively to NPK fertilizer as observed by Law-Ogbomo and Emokaro (2009) that the application of 300 $\mathrm{kg} / \mathrm{ha}$ NPK was found to be optimum rate for yam production. Diby et al. (2009) and Hgaza et al. (2010) in previous research had identified nitrogen and potassium as critical elements for good yam production which corroborated earlier reports of Okigbo (1980) on the respective amounts of these elements absorbed from the soil by yam during growth. The levels of nitrogen and potassium of 0.22 $\mathrm{g} / \mathrm{kg}$ and $0.32 \mathrm{cmol} / \mathrm{kg}$ respectively observed in Table 3 and the values of $0.23 \mathrm{~g} / \mathrm{kg}$ and $0.33 \mathrm{cmol} / \mathrm{kg}$ in Table 4 indicated medium range supportive of good seed yam performance. This assertion was however based on earlier report of Kparmwang and Malgwi (1997) on the categorization of nutrient status of tropical soils.

\section{Conclusion}

The nutrient status of the soils in the treatment plots of $\mathrm{P}+\mathrm{Hr}, \mathrm{P}+\mathrm{Hr}+\mathrm{R}$ and $\mathrm{MR}$ were supportive of good seed yam production. The difference in the seed yam yield could therefore be attributed to the different bulk density values and the corresponding soil total porosity. The comparable seed yam yield in $\mathrm{P}+\mathrm{Hr}+\mathrm{R}$ and $\mathrm{MR}$ indicated that mechanized ridging could be substituted with manual ridging. This could then eliminate the discontinuance and the apathy of small holder seed yam farmers who had stigmatized view of only a tractorized land preparation to be conducive for the production of seed yam.

\section{REFERENCES}

Agbede TM. 2005. Effect of tillage on soil properties and yam yield on an Alfisol in South western Nigeria. Soil and Tillage Research, 86(1): 1-8. 
Akintola JO. 1986. Rainfall Distribution in Nigeria, 1892 to 1983 . Impact Publishers Nigeria Ltd: Ibadan, Nigeria; 380pp.

Bamire AS, Amujoyegbe BJ. 2005. Economic analysis of land improvement techniques in smallholder yam-based production systems in the agro-ecological zones of southwestern Nigeria. Journal of Human Ecology, 18(1): 1-12.

Bolarinwa KK, Oladeji JO. 2009. Adoption and relevance of yam minisett technology practices to farmers indigenous practices in rain forest and derived savannah zones of Nigeria. Journal of Applied Sciences Research, 5(12): 24612465.

Brady NC, Weil RR. 1999. The Nature and Properties of Soils (12 $2^{\text {th }}$ edition). Prentice Hall: New Jersey; 881.

Carter MR. 1993. Soil Sampling and Methods of Soil Analysis. Canadian Society of Soil Science. Lewis Publishers: London; 823.

Chikwendu DO, Chinaka CC, Omotayo AM. 1995. Adoption of minisett technique of seed yams production in the eastern forest zone of Nigeria. Discovery and Innovation, 7: 367-375.

Diby LN, Hgaza VK, Tie TB, Assa A, Carsky R, Girardin O, Frossard E. 2009. Productivity of yams (Dioscorea spp.) as affected by soil fertility. Journal of Animal and Plant Sciences, 5(2): 494-506.

Ennin SA, Otoo E, Tetteh FM. 2009. Ridging, a mechanized alternative to moulding for yam and cassava production. West African Journal of Applied Ecology, 15:1-8.

Hgaza VK, Diby LN, Assa A, Ake S. 2010. How fertilization affects yam (Dioscorea alata) growth and tuber yield across the years. African Journal of Plant Science, 4(3): 053-060.

Ibana S, Odoemena B, Akintola JO, Ihedioha D, Okoli P. 2009. Constraints to the delivery of clean seed yams in the lowland subhumid tropics of Nigeria: The supply chain approach. African Journal of Agricultural Research, 4(4): 321-329.

Ijoyah MO, Aba J, Ugannyan S. 2006. The effects of seed bed types on yam minisetts yield: A case study of Ushongo Local Government Area of Benue State of Nigeria. African Journal of Biotechnology, 5(22): 2086-2091.

Ike PC, Inoni OE. 2006. Determinants of yam production and economic efficiency among small holder farmers in Southeastern Nigeria. Journal of Central European Agriculture, 7(2): 337-342.

Kparmwang T, Malgwi WB. 1997. The Genesis, Classification and Productivity Limitations of Sandstone soils in Northwestern Nigeria. Proceedings of the $23^{\text {rd }}$ Annual Conference of Soil Science Society of Nigeria (Singh BR. Ed.); 3-50.

Law-Ogbomo KE, Emokaro CO. 2009. Economic Analysis of the Effect of Fertilizer Application on the Performance of White Guinea Yam in Different Ecological Zones of Edo State, Nigeria. World Journal of Agricultural Sciences, 5(1): 121-125.

Madukwe MC, Ayichi D, Okolie EC. 2000. Issues on yam minisett technology transfer to farmers in southeastern Nigeria. African Technology Policy Working Paper No.21 African Technology Policy Studies (ATPS) Network, Nairobi.

Martinez LJ, Zinck JA. 2004. Temporal variation of soil compaction and deterioration of soil quality in pasture areas of Colombia Amazonia. Soil and Tillage Research, 75: 3-17.

Ndubisi I, Obinani OO. 1988. Evaluation of yam cultivars for seed yam production using the minisett technique. Field Crops Research, 19(2): 81-89.

Nnadi FN, Akwiwu CD. 2007. Farmers discontinuance decision behaviours of yam minisett technology in Imo State, Nigeria. International Journal of Agriculture and Rural Development, 9: 80-85.

Obigbesan GO, Agboola AA, Fayemi AA. 1976. Effect of potassium on tuber yield 
and nutrient uptake of yams. In Proceedings of the Fourth Symposium of International Society for Tropical Root Crops. CIAT. California, Columbia; 104107.

Odjugo Peter AO. 2008. The impact of tillage systems on soil microclimate growth and yield of cassava (Manihot utilisima) in Midwestern Nigeria. African Journal of Agricultural Research, 3(3): 225-233.

Oguntade AE, Thompson OA, Ige T. 2010. Economics of Seed Yam Production Using Minisett Technique in Oyo State, Nigeria. Field Actions Science Reports Volume 4. http://factsreports. revues.org/659

Okigbo BN. 1980. A review of cropping systems in relation to residue anagement in the humid tropics of Africa. In Organic Recycling in Africa. FAO Soil Bulletin 53, FAO: Rome; 13-37.

Okoli OO, Igbokwe MC, Ene LSO, Nwokoye JU. 1982. Rapid multiplication of yam by the minisett technique. Research Bulletin 2. National Root Crops Research Institute (NRCRI), Umudike, Nigeria, 12 pp.

Okoro FU 1999. Technological gaps in yam minisett technique among yam growers in Owerri Agricultural zone of Imo State, Nigeria. Journal of Agricultural Extension, 3: 122-128.

Okoro JK. 2008. Awareness and use of the rapid seed yam multiplication technology by farmers in Nigeria's Yam Belt. Production Agriculture and Technology (PAT), 5(1): 22-29.
Onwueme IC. 1978. The tropical tuber crops: Yams, cassava, sweet potato and cocoyams. Wiley: New York; 234.

Orkwor GC, Asadu CLA. 1998. Yam agronomy. In Food Yams. Advance in Research. Orkwor GC, Asiedu R, Ekanayake IJ (eds); 105-141.

Otoo JA, Osiru DSO, Ng SYC, Hahn SK. 1987. Improved Technology for Seed Yam Production. International Institute of Tropical Agriculture Ibadan; 56.

Periaswamy SP, Ashaye TI. 1982. Updated classification of some southwestern Nigeria Soils. Ife Journal of Agriculture, 4 (1\&2): 25-41.

Perlas FB, Ruiz RB, Pante RE. 2010. Field evaluation of selected yam (Dioscorea alata) accessions on acid soils and salineprone areas. $19^{\text {th }}$ World Congress of Soil Science $1^{\text {st }}-6^{\text {th }}$ August held in Brisbane, Australia.

Shehu JF, Iyortyer JT, Mshelia SI, Jongur AAU. 2010. Determinants of yam production and technical efficiency among yam farmers in Benue State, Nigeria. Journal of Social Science, 24(2): 143-148.

Udoh AJ, Idio A, Umoh E, Robson U. 2008. Socio-economic factors influencing adoption of yam minisett technology in southeastern Nigeria: A Probit Analysis. Indian Research Journal of Extension Education, 8(2\&3): 1-5. 